\title{
The Prague Spring of 1968 and its impact on religious life and state-church relations in Czechoslovakia ${ }^{*}$
}

\author{
M. Moravcíkova \\ Trnava University, \\ 23, Hornopotočná, 918 43, Trnava, Slovak Republic
}

For citation: Moravcíkova M. The Prague Spring of 1968 and its impact on religious life and statechurch relations in Czechoslovakia. Vestnik of Saint Petersburg University. Philosophy and Conflict Studies, 2019, vol. 35, issue 2, pp. 378-389. https://doi.org/10.21638/spbu17.2019.213

The oncoming of communism in Czechoslovakia in 1948 meant for churches and religious communities the "nationalization" of church property and the implementation of supervision through the State Office for Church Affairs. The communist state never thought about the separation of church and state, but rather assumed such a step would be in given historical conditions an increase in the social impact of churches. The consequence of the delegation of the Russian Orthodox Church in Czechoslovakia was a fusion of the Uniate Church in Slovakia with the Orthodox Church. The pressure on the church caused various illegal activities that became the target of persecution by state security forces. The Prague Spring was the culmination of attempts at social reform in Czechoslovakia that were intensively conducted after January 1968. The weakened grip on power and the overall trend of democratization led to a significant recovery in activities of churches, until they were suppressed in August 1968 by Warsaw Pact troops. The paper is an attempt to analyze the most significant reversal in church policy of Czechoslovakia in connection with the democratization of socialism under the influence of Alexander Dubček's reformism. It follows this development through the prism of Soviet Union concerns about the weak position of the Soviet bloc, as well as the suppression of reforms, and the subsequent establishment of the Slovak Republic in the framework of a socialist federation. It notes the role of civil society activists and Catholic dissidents who developed vastly different level of activity in both parts of the federation. Finally, it aims at the synthesis of knowledge of the interactions of religious institutions and elites and the communist government and political elites in the period around 1968.

Keywords: Czechoslovakia, Church-state relations, Prague Spring.

\section{Introduction}

During the post-war period, churches represented an influential political power in Czechoslovakia. According to a census ${ }^{1}, 99.72 \%$ of inhabitants identified with a church and only $0.28 \%$ claimed to have no religion. The Catholic Church of Latin (Roman Catholics) and Byzantine rites (Uniats, or Greek Catholics) was the biggest and most influential, comprising $82.75 \%$ [1, p. 13] of inhabitants ${ }^{2}$. Other significant churches were the Lutheran

* This research was undertaken under the auspices of a grant from the VEGA Grant Agency, contract no. 1/0172/17 "Associations as an element of democracy and the expression of freedom of association in public relations and private law."

1 For a period until March 1, 1950.

2 Out of which $76.20 \%$ were Roman Catholic and $6.55 \%$ Greek Catholic. Comp. [1, p. 13].

(C) Санкт-Петербургский государственный университет, 2019 
Church of Augsburg Confession and Calvinistic Church. Baptists, Adventists, Methodists, Orthodox, Hussites (Czech Reformed Church), Old Catholics, Jews, and other churches had only a minimum number of followers [2, p. 19n].

\section{Heritage of the Czechoslovak Republic and the Slovak State}

Within the People's Democratic regime, the government proclaimed and actually ensured the freedom of religion in practice. All churches showed loyalty towards the restored Czechoslovak Republic. In Slovakia, the situation of the Catholic Church was more complicated and its relations with state more tense when compared with other churches. It paid its bitter price for its ties with Hlinka's Public Party - the creator and bearer of the reign and force in the Slovak Republic ${ }^{3}$ between 1939-1945. The ban on Hlinka's Public Party and a lawsuit with Tiso and other state representatives also harmed the Catholic Church, as the dividing line between the Catholic Church and political Catholicism was not firm. The government had a negative attitude towards the majority of Catholic bishops who were connected with Tiso's former regime [3, p. 233-241].

Jozef Tiso ${ }^{4}$ was a Slovak Roman Catholic priest and a leading politician of the Slovak People's Party. Between 1939 and 1945, Tiso was the head (president) of the 19391945 First Slovak Republic, a satellite state of Nazi Germany, and he was to remain an active priest throughout his political career. After the end of World War II, Tiso was convicted and hanged for treason that included war crimes and crimes against humanity as judged by the National Court in Bratislava [4, p. 545-553].

Chief representatives of the Lutheran Church of Augsburg Confession had close political contacts with post-war, predominantly Lutheran, leadership of the Democratic Party. The Reformed Christian Church (Calvinists) was divided after the war in connection with sharp Slovak-Hungarian relations. Slovak clergy stood at the head of the church, whose majority was comprised of believers in Hungarian nationality. The majority of clergy of Hungarian nationality did not have state citizenship and could not perform official functions within the church in Czechoslovakia. Thus, their impact on social events was minimal. The Jewish religious community had been decimated.

\section{Events of February 1948 and their outcome}

By the February subversion in 1948 and shortly thereafter, the dismantling of what was left of democracy in Czechoslovakia came to its peak as Communists took power. The prior interest of communist regime was to manipulate churches according to its own interests via their representatives. However, when these steps did not prove effective, communist forces put the center of anti-church activities on minimizing its social influence and establishing strict state control.

3 The (First) Slovak Republic or the Slovak State was a client state of Nazi Germany and existed between 14 March 1939 and 4 April 1945. It controlled the majority of territory in present-day Slovakia, but without its current southern and eastern parts, which had been ceded to Hungary in 1938. The Republic bordered Germany, the Protectorate of Bohemia and Moravia, Poland (and subsequently the General Government (German-occupied remnant of Poland), and Hungary. The contemporary Slovak Republic is not considered its legal successor state.

${ }_{4}^{4} 13$ October 1887 - 18 April 1947. 
Prior to 1948, antichurch policy began to apply mainly in Slovakia. Any Catholic activity in Slovakia was marked as an upcoming putch or conspiracy, and so on. One target of early attacks was the rings of the Catholic Action known as Family, which since 1943 formed, in particular in Bratislava, by the acting Croatian priest Tomislav Kolaković, a former Jesuit. This lay movement anticipated changes in the view of the status of laity in the Church and in the world, which appeared later in documents of the Second Vatican Council. The apprehension of members of the Family, known as the unveiling of the antistate plot, began in December 1945.

When the state isolated the Church from Rome and banished it from the walls of the churches on 15 June 1949, bishops issued a leaflet known as the Voice of Bishops and Ordinaries at the Great Examination Hour. Except for all the religious press, all Catholic books were subjected to preliminary state censorship, and Catholic publishers were appointed as state agents. Any gathering of Catholics outside the church was forbidden. All church schools were abolished. The state refused to negotiate with the Vatican, and also denied the possibility of a convention with bishops. They either physically deposed them or attempted to steal them structurally.

The first strategic attempt on the part of the state to end the bishops' struggle structurally was the so-called Catholic action as a "movement of progressive Catholics" movement, so declared on June 10,1949, became the chief spokesman for the Church and the state's partner. For frequent misunderstandings, but also under coercion, an initial statement of 1500 clergy and thousands of believers was signed. The above-mentioned pastoral letter was also a response to this situation. The Communists did not succeed in this move and the organization vanished around June 1951.

The failure of Catholic action can be attributed, in particular, to the prompt issuance of the Excommunication Decree of 20 June 1949 by the Supreme Holy Congregation of the Holy See, which condemned the Catholic Action. On its basis all who voluntarily and knowingly approached or even acceded to it were excommunicated. An even more serious excommunication decree, shortly known as the Decree on Communism, was issued on July 1, 1949, and was never abolished. It was not new legislation, but a legal interpretation of existing legal standards. The Sacred Officer made the interpretation so that believers who advocate or promote "materialist and anti-Christian teaching of communists" fell into excommunication as apostates from Catholic faith. However, the Exclamation Decrees could not be directly applied in Czechoslovakia for an exceptional situation. Indeed, their public reading itself has been the reason for the loss of freedom or at least an aggravating circumstance in the trial of another "criminal" act ${ }^{6}[5]$.

During 1949, the state prepared a set of laws and state regulations known as "Church Laws." They codified the subordination of state churches; all church activities of were unconditionally bound to state approval. The state took over all economic obligations associated with church activities, especially salaries of the clergy, repairs of buildings, and the

${ }^{5}$ The state abused the name of the long-standing church movement.

${ }^{6}$ According to historian Karel Kaplan, the Church's laws were unacceptable for the following reasons: a) the highest church authority was the State Office for Church Affairs; b) the bishop, but the state, did not decide on the establishment of the spiritual at a particular place; c) the clergy have become dependent on the state; d) the promise of loyalty did not respect the Church's obligations; e) the state has taken control of religious education and the Church press; $f$ ) the patronage did not disappear but was taken over by the state; g) the state authorities were conscripted under the enactment of the 1784 enactment law which, although lost, was still in force, but the communists continued to use it. 
performance of the cult itself. State approval for the exercise of activity could have been taken away at any time by the spiritual side. The Criminal Code was supplemented by a criminal offense in violation of the Church Security Act. This offense was committed at a time when the religious person committed a religious act without a state consent, anywhere, even in his own apartment.

Act no. 217/1949 Coll. created the State Office for Church Affairs as a central organ of state administration. One year later a new law, Act no. 218/1949 Coll. on economic provision of churches and religious associations by state, was passed. This regulation enabled the state to differentiate its approach towards clergy. This act also brought into existence the institute of "state approval" for clergy.

Churches and religious associations ceased to have the character of subjects of public law and became completely dependent economically on the state. The majority of church property and church schools were nationalized. The state gained control over liturgical, pastoral, social, charity, educational, economic, and any other church activity. It established compulsory registration of churches; the clergy could perform public performances only if approved by the state. This approval was conditioned by their vow of loyalty to the republic.

The Communist state had never considered the separation of the church from the state. It assumed that such a step within given historical conditions would raise the social influence of churches and strengthen the discipline of the clergy towards the church hierarchy. This represented a counter-productive element for a state struggling to dissolve churches from within. Naturally, strict totalitarian control of churches activated illegal activities by individual believers, clergy, or various groups that were out of the reach of state control. They became the target of persecution by national security forces.

The period 1948-1953 represented a situation of extremely acute conflict in statechurch relations. Churches resisted interference into their internal matters and restriction of religious freedom with remarkable intensity. During the following stage, state power concentrated on "overcoming religious relics" through state interventions as well as party and state structures supporting secularization and atheisation of society. Some bishops, priests and, monks were imprisoned. Vacant positions of church hierarchs were occupied by administrators appointed by the communist government. The state also had its attendants on bishop ministries who controlled the activities of episcopacies [6, p.311].

In August 1948 communists came with an idea to create a national Catholic Church. Because of the ceremonial and disciplinary differences between Roman Catholics and Greek Catholics they consequently started to sort out the "Greek Catholic issue." They proposed a "return" of Greek Catholics into the Orthodox Church. In 1946, a so-called "sobor" (council) took place in Lvov, western Ukraine. Here, the union with Rome was abolished and a return of Greek Catholics to the belief of their ancestors, to the Orthodox $\mathrm{Church}^{7}$, was proclaimed. Since the standpoints and acts of Russian communists were authoritative for Slovak communists, a similar procedure was chosen in Slovakia. After a visit by a delegation of the Russian Orthodox Church to Czechoslovakia (whose aim was to prepare the fusion of Greek Catholic and Orthodox church in Slovakia), this political plan was given the name Action P. On April 28, 1950, the sobor (council) of Greek Catholics, with participation by Greek Catholic delegates appointed by the state, took place

\footnotetext{
${ }^{7}$ Later on, similar actions of liquidation were taken against Uniat Church in Romania and CarpathianUkraine.
} 
in Prešov. It took the decision to abolish the Uzhorod Union from 1646, the separation from Rome, and the return to "father" Orthodox Church. At the same time it addressed Orthodox Patriarch of Moscow and all Russia to accept it under his church jurisdiction. On May 27, the Exarch of The Orthodox Church in Czechoslovakia, Jelefterij, received a letter from the State Office for Church Affairs. The letter acknowledged the legitimacy of decisions taken by Prešov sobor. From the state's point of view, the Greek Catholic church ceased to exist in Slovakia. Greek Catholic clergy, who refused to enter the Orthodox Church, had to give up their clerical profession. In most cases they were interned and later transferred to Czech-German border region to work in agriculture or blue-collar jobs. Two Greek Catholic bishops were convicted of seditious activities and sentenced to prison for a long period. Along with the liquidation of the Greek Catholic Church, monasteries and holy orders were also closed down as the response to their significance within the Catholic Church and influence they had on the society.

At the break of March and April 1950, in an artificially constructed lawsuit against monastery and holy order representatives, monasteries were "revealed" as centers of sedition, where espionage was organized, weapons collected, and provocations prepared. Action $K$ took place on the night April 12-13, 1950. Security forces seized a majority of monasteries and monks were sent to detention camps. Even though massive security forces were put in operation, several sharp crashes took place. A similar intervention against women's holy orders followed as a part of Action R. Interned nuns and monks were first re-educated and afterwards transferred to work in factory production, with nuns in particular sent to Czech border region to work in the textile industry.

After 1950, theological studies were available only at the Constantine-Methodius Theological Faculty in Bratislava and at Orthodox Theological Faculty in Prešov. All other theological institutes were closed down. The state took strict actions against "reaction" priests, who were often imprisoned without a lawsuit or sentenced to military service to carry out hard labor in subsidiary technical battalions of army forces.

At the beginning of the 1950s, hundreds of clergy were imprisoned or interned. Bishops were isolated and interned in the bishops' ministries or imprisoned. As for the Catholic Church, a parallel church structure began to flourish illegally. It took over some functions of the official Church. The state, on the other hand, organized "Catholic clergy peace movement," in which it strived to establish connections among priests willing to cooperate with the state. In doing so, the state could differentiate the Catholic Church in Czechoslovakia. However, membership ended up low and the movement did not have a significant influence on the society. Evangelical churches in this period did not resist the state strongly; the Calvinist Church found importance in the national problem and not the problem of loyalty towards the regime. The church press was a subject to state control to such extent that in fact it did not have religious character any longer [1, p. 20-21].

In 1958 new Pope John XXIII was more peaceful towards Communism, especially with his successor Paul VI linked with so-called "Vatican Ostpolitik". It originated in the early 1960s under in the belief that Communist regimes were stable. The Holy See first called for freedom for bishops. As early as November 1963, the leader of the Vatican delegation, Agostino Casaroli, interpreted the Pope's satisfaction with the dismissal of imprisoned and interned bishops in Prague. Negotiators agreed to add a loyalty phrase to their pledge. Based on negotiations, he prepared the departure of the Archbishop of Prague, Josef Beran, to Vatican exile. In 1968, in Czechoslovakia, the spirit of the Second Vatican 
Council documents also sparked. It began to operate the Opus of Council Reconstruction led by bishops, leaning on a wider organizational basis, in which both laymen and lay attended. In Bohemia, three bishops who retired to the office for 20 years were renamed into pastoral care. In Slovakia, Bishop Vasil Hopko again assumed the functions of the GreekCatholic Church as part of the restoration of the Greek-Catholic Church.

\section{Prague Spring 1968}

Before 1968, the first symptoms of change in church-political situation appeared, mainly under the influence of Marxist-Christian dialogue that was popular especially with French and Italian communists. The dialogue with Christians found one of the specific instruments of ideological battle for suppression of religious ways of thinking with believers. Sporadically, requests to recompense the wrongdoing to believers and churches appeared.

The Prague Spring in 1968, when Alexander Dubček became the first secretary of Communist Party, began certain democratization processes along with a new state church policy. The censorship of the church press was eased, the "cadre ceiling" for the religious was cancelled, and communication between Catholic ordinaries and the Holy See was allowed. The government passed a decree that approved the activity of Greek Catholic Church. Limits for accepting candidates for priesthood to theological faculties were cancelled. The Supreme Court was asked to go through the processes with Catholic hierarchy, representatives of monasteries, and the like. Many officials and members of Communist Party reproached such an attitude against Party leadership. However, party bodies planned changes of a larger extent within church policy after proposed changes in the legal norms of 1949. These processes were much more striking in the Czech Republic than in Slovakia. The dialogue between Marxists and Christians in Slovakia did not take place at all.

The occupation of Czechoslovakia by armies of five Warsaw Pact states in August, $21,1968^{8}$ put a brake on democratization and a process of so-called normalization was initiated. Representatives of hard-line forces replaced pro-reform Party and state officials. They supported the exclusion of churches from state control. A regress in church-political situation and a return to state-church relations from before 1968 followed. A new, statecollaboration movement of Catholic clergy - Pacem in terries ${ }^{9}$, - was initiated. Through this, the Communist Party wanted to penetrate the Church and influence its activities according to Party interests. State-church relations were reduced to church-political control and suppression of any church activities and public religious manifestations. Time-con-

8 The Warsaw Pact invasion of Czechoslovakia, officially known as Operation Danube, was a joint invasion of Czechoslovakia by four Warsaw Pact nations - the Soviet Union, Bulgaria, Hungary and Poland - on the night of 20-21 August 1968. Approximately 250,000 Warsaw pact troops attacked Czechoslovakia that night, with Romania and Albania refusing to participate. Although East German forces were prepared to participate, they were ordered by Moscow not to cross the Czechoslovak border just hours before the invasion. 108 Czechoslovakian civilians were killed and around 500 wounded in the invasion. The invasion successfully stopped Alexander Dubček's Prague Spring liberalization reforms and strengthened the authority of the authoritarian wing on the Communist Party of Czechoslovakia (KSČ). The foreign policy of the Soviet Union during this era was known as the Brezhnev Doctrine.

${ }^{9}$ John Paul II issued the Quidam episcopi bulla (Manifest of Holy Congregation for the Clergy about some associations and movements prohibited to clergy) in the beginning of March 1982. According to the bulla, those associations and movements are alien to priest service, which directly or indirectly, openly or secretly pursue political goals, even though they sometimes present them in a way as if they tried to support humanistic ideals, peace and social progress. 
suming negotiations between Czechoslovakia and the Holy See were an exception. They negotiated about filling the vacant bishop seats, about theology faculties, and reorganization of the diocese boundaries so they did not overreach state boundaries. Pope Paul VI used the Praescriptorum Sacrosancti constitution from December 30, 1977 to create the Slovak church province with a seat in Trnava ${ }^{10}$. The pressure of the Holy See as well as international pressure to realize Helsinki commitments in Czechoslovakia consequently became stronger after Karol Wojtyla's accession as Pope. Church activity increased; believers showed their discontent with state policy towards churches and religion and demanded real religious freedom. Religious pilgrimages became events of resistance; the number of lay religious activists grew. On March 25, 1988, a manifestation that entered history as "candle manifestation" took place in Bratislava. Some thousand people from the whole republic found the courage to gather at Hviezdoslav Square. Carrying candles in their hands they demonstrated their support of requests to defend religious and human rights. After the crowd did not respond to the call to disperse, a strong intervention of security forces followed. This was one of the regime's last uses of power before its eventual downfall. In spite of the fact that external events ${ }^{11}$ influenced the downfall of the regime, we cannot ignore activities of churches and Catholic dissent. The latest mentioned was one of the strongest bodies representing the communist regime resistance in Slovakia.

\section{Czechoslovak Communist Party and Religion}

Let us return to the Prague Spring. This began with the election of Alexander Dubcek as the first secretary of the Central Committee of the Communist Party of Czechoslovakia. Officially, the Communist dialogue with Christians was considered to be a communist struggle to overcome religious thought (secularization of society). This were followed of the work of communist academics: lectures by Marxist philosophers M. Machovec and V. Gardavsky, sociologists E. Kadlecová, J.Hranička, and J.Prokupek. In the 1960s, the Commission for the Theory and Sociology of Religion was established at the Czechoslovak Academy of Sciences. In 1967, an international scientific conference on Marxism and Christians was held in Mariánské Lázně, where about three hundred scholars, including theologians, took part. Protests against the conference not only had Czech and Slovak communists, but also communists from the Soviet Union, the German Democratic Republic and Poland.

The issue of church policy was traced by the Communist Party presidency in March 1968. The material "Observations on the Concept of the Church-Political Work and the Society - Proposals for further action" was organized. The document suggests that Communists feared, in particular, that the initiative of the struggle for religious freedom was taken over by the clergy or the Lidová strana (People's Party). Communists were afraid of losing "political initiative" and leadership in society.

An "Action Program" was created that included the following: investigating cases of prisoners that concerned religion; removing obstacles to normal religious life in the country; accepting representatives of individual churches and reporting positive changes

10 The Qui divino constitution from the same day promoted the Trnava diocese to archdiocese.

${ }^{11}$ We should not forget to mention the official visit of the president of the Soviet Union, Mikhail Gorbachev, to Czechoslovakia in 1987, during which he proclaimed that the Soviet Union could not intervene in the internal development of its satellite states. 
(related to the democratization of society); exchanging people in state structures that included a Church agenda; and adopting changes in law that already did not allow arbitrary interference in the religious affairs of the state.

The implementation of these measures provided the Communist Party with control over events and gained time for a conceptual solution to Church policy. There were no meetings with individual representatives of the churches, but a meeting between Minister of Culture and Information Karol Hoffmann and Bishop František Tomášek. Staff exchanges took place at the Secretariat for Church Affairs. Finally, the Minister of Culture was also replaced. New faces should bring about a new church policy.

In fact, many other changes also occurred: the abolition of censorship of the Church press and the abolition of the ban on assembly. From preserved documents (The Administration of the Ministry of Culture and Information on the Church Political Situation of July 1968) it follows that the state authorities should apply a differentiated approach to individual groups (believers, clergy) to get the most influential individuals to cooperate. The authors of the report "sought the optimal form of integrating churches and believers into the system of democratic socialism". Therefore, they did not have to comment on the socio-political process. The Communists perceived it as a role for their political party. The churches were to be members of the Commission of the National Front, which brought together non-political associations (such as beekeepers, gardeners, fishermen, amateur actors etc.). The report emphasized a different approach to this issue in the Czech and Slovak Republics because of a different thirty-year development in both parts of the republic. Future president and later Deputy Prime Minister G. Husák was responsible for church politics. Independent national authorities for the supervision of churches were established. In the end, they brought more perfect churches and believers in both parts of the republic.

The Communists also discussed the formulation of the Constitution of MarxismLeninism as the official ideology of the state. There was a draft text that emphasized science and the needs of socialism in education. Another issue was the relationship of the Communist Party to religion. Two principles were adopted by the KSČ presidency (16 July 1968): the Communist Party will be non-religious, but will respect the religion of citizens.

The preserved reports from the presidency of the Communist Party of Czechoslovakia show that church politics was the most traded and most controversial among the members of the presidency [7]. The key issue was the meeting of the Communist Party Presidency, which aimed to develop a "new concept of the Communist Party's relationship to religion" by September 30, 1968. However, in August 1968, the situation changed radically.

\section{Normalization and its consequences}

In the new structures of the Communist Party, especially after mid-1969, there was a conviction that the church went out of control over the past year. The "restoration of authority" of state authorities was the main objective of the Communist party. Key negotiations took place on September 9, 1969, October 10, 1969, and December 10, 1969. The frequency of the meetings demonstrates the importance of the "church issue". The document "Information on the Church Political Situation" and "Proposals of Political Procedures in the Field of Church Policy" were adopted. These documents became the core of the "Nor- 
malization" program in the field of church policy and the creation of an "adequate" form of relations between the state and the churches [8, p. 26n].

In practical terms, the task was to create an association of clergy who would cooperate with the Communist Party. This also included a return to the Progressive Peace Movement of Catholic Clergy ${ }^{12}$ and the management of the Svaty Vojtech Society by communists. On 26 January 1970 the Minister of Culture (in Slovakia), M. Válek, met all church hierarchs and asked them to strictly abide by the laws governing the relationship between the state and churches. This was followed by forced personal changes at the bishoprics (Rožňava, Košice, Banská Bystrica, Spišské Podhradie). Personal cleansing was gradually extended to lower organizational units of the churches, including the withdrawal of the state's approval by the individual priests. By mid-1986 the regime had prohibited more than 500 of an approximate 3,200 Roman Catholic priests from ministering.

The onset of normalization and specific events triggered the resistance of believers and the clergy. The resistance was manifested by petitive activities, by writing applications (to the government, Communist Party, Holy See). Activists wanted to maintain the 1968 status quo. The reactions were forced to move the most active priests to the most difficult accessible settlements, and later to arrest them. Likewise, state power also employed against active laymen. Representatives of Communist power began to select candidates for seminars. Some priests and bishops responded to it by the secret education of the priests. There were underground structures of the church, such as a parallel church or taking on the activity of existing underground religious activities. Theology departments continued to operate under strict admission quotas, and staffing problems grew throughout the 1970s. Chief Rabbi Richard Feder died in 1970, leaving the Czech Jewish communities without rabbinical direction until 1984. (Slovakia's rabbi was Samuel Grossman.) The new chief rabbi for the country, Daniel Mayer, studied for the rabbinate in Budapest. In 1972 the death of three Roman Catholic bishops and the revocation of state approval of a fourth exacerbated the already acute shortage of Roman Catholic leaders. Talks between the Vatican and the regime were sporadic through the 1970s and produced few material gains for Czechoslovak Roman Catholics. The perennial conflict remained: the appointment of regime loyalists in opposition to choices for parish and diocesan posts. In 1986, out of thirteen church offices, nine bishoprics were vacant and two archbishoprics (Olomouc and Trnava) had only bishops holding office.

Religious teaching was returned to schools (second to seventh year of elementary school). However, the aim of the seemingly positive step of the Communist Party was to find out the number ${ }^{13}$ and names of individuals who came from "ideologically defective" families. The state stopped paying priests who taught religion in schools because teaching religion was a part of their pastoral activity. During the Prague Spring religious orders became visible. In 1970 the Communist Party issued a ban on accepting novices and novices. It sought to extort these church structures only into charitable activity. It was forbidden for members of orders to perform catechetical activity. The implementation of this ban was, however, problematic. The Ministry of Culture drafted "Directives for activities

12 Finally, the Pacem in terris movement was created in 1971.

13 The number of children in the school year 1970/71 was 53.10\%, in the school year 1969/70 62.29\%, and in the school year $1967 / 68$ only $39.78 \%$. 
of religious societies" 14 . Its essence was to concentrate religion into religious homes and eliminate their influence in a society.

The international political dimension of the normalization of the church policy was manifested in relations with the Holy See. The state was steadily delaying and shifting planned negotiations with the Holy See, which itself was interested in discussing bishops' affairs, changes in "Church Laws", establishing the Slovak Church Province, legalizing religious life, setting up seminars for priests, and so on. Finally, after a long delay in the negotiations, they began. At the beginning of 1973, four new bishops were appointed in Slovakia, approved by both the Communist Party and the Holy See.

Normalization affected all churches, but to different degrees. The punishing of the churches was directly proportional to their loyalty in 1968. The most persecuted was the Catholic Church. Protestant and Jewish groups were also harassed, but Orthodox churches and the Czechoslovak National Church were generally spared. In an effort to ensure compliant and loyal clergy, the regime of G. Husák organized a number of state-controlled associations, including the Ecumenical Council of the Churches of the Czechoslovak Socialist Republic and the Czechoslovak Association of Catholic Clergy (more commonly known as Pacem in Terris), with Czech and Slovak branches. However, in late 1980, there were signs of a temporary worsening church-state relations. In October a number of students at the Cyril and Methodius Faculty of Divinity in Bratislava began a hunger strike in protest against Pacem in Terris.

The Czechoslovak Constitution permitted freedom of religion and expression, but in the 1980s citizens were well advised not to take these guarantees too literally. Statecontrolled organizations existed for most religious creeds except Jehovah's Witnesses, who were prohibited. The most prominent was the Roman Catholic Church. There were also a variety of Protestant denominations, including the Czechoslovak Baptist Church, the Lutheran Church of Czech Brethren, the Slovak Lutheran Church, the Seventh-day Adventist Church, and the Methodist Church of Czechoslovakia. Also represented were the Czechoslovak National Church, the Uniate Church, and Jewish communities. In 1981 a number of church dignitaries stood before the Czechoslovak minister of culture to take a vow of loyalty to the Czechoslovak Socialist Republic.

A development that was particularly distressing to the authorities was growing interest in religion by younger people in Czechoslovakia. In 1985, of the more than 100,000 people who took part in celebrations relating to the $1,100^{\text {th }}$ anniversary of the death of Saint Methodius ${ }^{15}$, Cardinal Tomášek noted that "two-thirds of the pilgrims were young people" [9].

\section{Conclusion}

The basic concept of Church policy, formed in the period 1948-1950, was (except for 1968) constant until the fall of Communism in November 1989. However, the internal and external conditions that characterized its realization were noted. The internalpolitical development in Czechoslovakia after January 1968, after the arrival of A. Dubček as Communist leader, created conditions for the rise of the activities by all churches. The most notable was the influence of the major Roman Catholic Church and the restora-

\footnotetext{
14 Published on July 30, 1970.
}

15 Velehrad 1985. 
tion of the previously forbidden Greek-Catholic Church. The Lutherans and Calvinists were mostly concerned with their internal problems during the Prague Spring period. The occupation of Czechoslovakia in August 1968 stopped this trend and created space for "normalization." Churches were once again pressed after a short period of freer life (only a few months). "Normalization" (standardization) froze the old problems of the believers as well as nternal problems of churches. The relationship between Orthodox and Greek Catholics worsened.

However, the residual of the Prague Spring spirit proved its viability. In addition to the influence The Vatican Council and its documents, there also existed international pressure: negotiations on security and cooperation in Europe (Helsinki 1975, Belgrade, 1976), human rights and freedoms, including freedom of conscience and faith, have always been brought to attention. Although Czechoslovakia was in a deep depression under the influence of "Normalization", the methods of the Church's persecution were not so effective already. Catholic dissent (in Slovakia and Moravia) and liberal dissent (in Bohemia) were already preparing their activities. This resulted in Charter 77, Candle Manifestation, and finally in November 1989.

\section{References}

1. Pešek, J. and Barnovský, M. (1999), Pod kuratelou moci. Cirkvi na Slovensku v rokoch 1953-1970 [Under the curse of power. Church in Slovakia in the years 1953-1970], Veda Publ., Bratislava.

2. Petranský, I. (2001), Štát a katolícka cirkev na Slovensku 1945-1946 [State and Catholic Church in Slovakia 1945-1946], Garmond Publ., Nitra.

3. Laclavíková, M. (2007), "The legal history of Slovakia as part of the Czechoslovak Republic 19181938", in Giaro, T., ed. Modernisierung durch Transfer zwischen den Weltkriegen, Vittorio Klostermann, Frankfurt am Main, pp. 233-241.

4. Mosný, P. and Laclavíková, M. (2016), "Slovak and Slovak statehood of 1939-1945 or should we at last accept our constitutional past?", Historický časopis, vol. 64, is. 3, pp. 545-553.

5. Kaplan, K. (1993), Stát a církve v Československu v letech 1948-1953 [The State and the Church in Czechoslovakia in 1948-1953], Doplněk, Brno.

6. Pešek, J. and Barnovský, M. (1997), Štátna moc a cirkvi na Slovensku 1948-1953 [State Power and Church in Slovakia 1948-1953], Veda Publ., Bratislava.

7. Party and Religion (1966-1970), in Material for the Presidency of Communist Party of Czechoslovakia, July 16, 1968, SÚA Praha, A ÚVKSČ, f. 2/1, vol. 76, vol. 106.

8. Pešek, J. and Barnovský, M. (2004), V zovretí normalizácie. Cirkvi na Slovensku 1969-1989 [In normalization. Church in Slovakia 1969-1989], Veda Publ., Bratislava.

9. Daniška, J., "Pút', ktorá zmenila dejiny" [Pilgrimage that changed history], in Konzervatívny denník Postoy, available at: https://www.postoj.sk/4916/put-ktora-zmenila-dejiny (accessed July 1, 2018).

Author's information:

Michaela Moravcíkova - Dr. Sci. Theology, Professor; vyb83@yandex.ru 


\title{
Пражская весна 1968 года и ее влияние на религиозную жизнь и отношения между государством и церковью в Чехословакии*
}

\author{
М. Моравчикова \\ Трнавский университет, \\ Словакия, 918 43, Трнава, Хорнопоточна, 23
}

Для цитирования: Moravcíkova M. The Prague Spring of 1968 and its impact on religious life and state-church relations in Czechoslovakia // Вестник Санкт-Петербургского университета. Философия и конфликтология. 2019. Т. 35. Вып. 2. С. 378-389.

https://doi.org/10.21638/spbu17.2019.213 (In English)

Приход коммунизма в Чехословакии в 1948 г. повлек за собой национализацию имущества церквей и религиозных общин, а также установление над религиозными организациями государственного контроля через Управление по делам Церкви. Коммунистическое государство в Чехословакии никогда не задумывалось об отделении церкви от государства, считая, что такой шаг в данных исторических условиях повлечет за собой усиление социального воздействия религиозных организаций. Под давлением Русской православной перкви в Чехословакии произошло слияние общин католиков восточного обряда («униатов») с православной церковью. Проблемы, возникавшие в церковной среде, приводили к волнениям, которые привлекали внимание государственных органов безопасности. Пражская весна стала кульминацией социальных реформ, которые начали активно проводиться с января 1968 г. Ослабление государственного контроля и демократические процессы способствовали восстановлению деятельности церквей, но все это в августе 1968 г. в страну были введены войска стран Варшавского договора. Статья представляет собой попытку проанализировать наиболее важные моменты в церковной политике Чехословакии в связи с демократизацией социализма под влиянием реформ Александра Дубчека. Эти преобразования усилили озабоченность Советского Союза проблемами стран социалистического блока, что стало причиной подавления реформ и последующего создания Словацкой Республики в рамках чехословацкой социалистической федерации. Анализируется роль гражданских активистов и католических диссидентов в обеих частях федерации. Предпринимается попытка создания общей картины взаимодействия религиозных институтов и элит, а также коммунистического правительства и политических элит в исследуемый период.

Ключевые слова: Чехословакия, церковно-государственные отношения, Пражская весна.

Статья поступила в редакцию 10 июля 2018 г.; рекомендована в печать 7 февраля 2019 г.

Контактная информация:

Моравчикова Михаэла - д-р теологии, проф.; moravcikova@gmail.com

* Исследование выполнено при финансовой поддержке VEGA Grant Agency under the contract no. 1/0172/17 "Associations as an element of democracy and the expression of freedom of association in public relations and private law". 